7. Reprod. Fert. (1968) 17, 139-146

\title{
LACTATE DEHYDROGENASE ACTIVITY IN THE OOCYTES OF MAMMALS
}

\begin{abstract}
RALPH L. BRINSTER
King Ranch Laboratory of Reproductive Physiology, Department of Animal Biology, School of Veterinary Medicine, University of Pennsylvania, Philadelphia, Pennsylvania

(Received 9th October 1967)

Summary. The mature oocyte dissected from the post-pubertal ovary has a lactate dehydrogenase activity similar to that found in the newly ovulated ovum in the mouse, rat, hamster and rabbit. There is very little interstrain or interbreed variation in LDH activity in the mouse and rabbit. Interspecies variation of activity is large. The lactate dehydrogenase activity was 49.10 (mouse), 17.66 (rat), 12.35 (cow), 6.65 (ferret), 6.32 (Rhesus monkey), 1.63 (rabbit) and 1.30 (human) $\times 10^{-9}$ moles of $\mathrm{NADH}$ oxidized/oocyte/hr.
\end{abstract}

\section{INTRODUCTION}

The pre-implantation stages of the mouse embryo have an extremely high lactate dehydrogenase (LDH) activity (Brinster, 1965a). The specific activity is ten times higher than in any other tissue in the adult mouse. Lactate or pyruvate, but not glucose, when employed as the only energy source, will allow in vitro development of the 2-cell mouse embryo (Brinster, 1965b). The pre-implantation stages of the rabbit embryo have a low lactate dehydrogenase activity and do not appear to have a requirement for lactate for in vitro development (Brinster, 1967). This information suggests that a high LDH activity is associated with a requirement for lactate or pyruvate during the early developmental stages.

Because of the high LDH activity in the pre-implantation mouse embryo, and because of its apparent association with a nutritional requirement for lactate or pyruvate, a study was undertaken to determine lactate dehydrogenase activity in the early developmental stages of other mammalian species. Since cleavage stages are difficult to obtain in some species, the first experiments, which are reported here, were done on oocytes dissected from the ovaries of animals. Studies were done to determine: (1) the time during which the ovary could be stored before removal of the oocytes; (2) the relationship of activity in the oocyte to that in the newly ovulated ovum; (3) interstrain and interbreed variation in LDH activity; and (4) interspecies variation in LDH activity.

\section{METHODS}

To obtain oocytes, ovaries were removed from post-pubertal females and dissected free of all surrounding tissue. The ovaries were placed in Brinster's 
Medium for Ovum Culture (BMOC-2), and mature follicles were opened with a sharp needle or iridectomy scalpel (Brinster, 1965c). Small ovaries, in which the follicles were not visible, were pulled apart with dissecting needles. The contents of the follicles were released into the medium by one of the above methods and picked up with a Pasteur pipette. Cumulus cells and the corona radiata were removed by drawing the oocyte back and forth in a narrow pipette. The cumulus cells can also be removed with hyaluronidase and, in some species, this enzyme will remove the corona cells as well. However, in the rabbit and many other species, the corona cells must be removed by mechanical methods. The denuded oocytes were then washed three times in BMOc-2 (without energy substrates) to remove cellular debris and energy compounds from the medium containing the oocytes. Finally, the oocytes were placed in small tubes and stored at $-70^{\circ} \mathrm{C}$. Generally only one oocyte was placed in each tube. The freezing adequately disrupts the cell and allows the enzyme to escape. Multiple freezing and thawing or removal of the zona pellucida does not increase enzyme activity (Brinster, 1965a).

Lactate dehydrogenase activity was determined spectrophotometrically from the rate of oxidation of $\mathrm{NADH}$ at $37^{\circ} \mathrm{C}$. Readings were taken at 3-min intervals and the rate was linear for at least $30 \mathrm{~min}$. Extinction readings were made in a Beckman model DU spectrophotometer which was modified with a precision cell positioner and micro cells for the micro method (Greenberg \& Rodder, 1964). In the macro method, the reaction mixture consisted of $1 \mathrm{ml}$ of $50 \mathrm{~mm}$-phosphate buffer, $0.1 \mu$ mole of NADH, and $1.0 \mu$ mole of sodium pyruvate. In the micro method, the reaction mixture consisted of $100 \mu \mathrm{l}$ of $50 \mathrm{~mm}$ phosphate buffer, $0.01 \mu$ mole of NADH, and $0.1 \mu$ mole of sodium pyruvate. The reaction was initiated by the addition of pyruvate and the decrease in absorbance due to NADH oxidation for the first $15 \mathrm{~min}$ was used to calculate the activity of the enzyme.

Statistical analyses were done on the results using Student's $t$-test. If the variances of the data to be compared were significantly different, a Behrens-Fisher test was used (Fisher \& Yates, 1963). The mean, the standard error of the mean, and the number of determinations on which the mean is based are shown for all data.

\section{RESULTS}

Storage of the ovary

The first studies were to determine if there was a loss in the LDH activity of the oocyte during the time the oocyte was being dissected from the ovary or during the time necessary to transport the ovary from the surgery area to the laboratory. Activities were compared in oocytes taken from mouse ovary pairs; one member of the pair was stored for $6 \mathrm{hr}$ at $22^{\circ} \mathrm{C}$ in BMOC-2 plus $1 \mathrm{mg} / \mathrm{ml}$ glucose and the other member was not stored before removal of the oocytes. The results of two such experiments are shown in Table 1. There was no significant difference between oocytes which were stored $6 \mathrm{hr}$ and those removed immediately. Longer storage periods gave variable results but, in some cases, storage overnight caused only a moderate decrease in activity. 
Activity in oocytes compared to ovulated ova

To determine how accurately LDH activity of the oocyte reflects activity of the newly ovulated ova and early cleavage stages, comparisons were made in several species. Lactate dehydrogenase activity measurements on oocytes and 2-cell Swiss mouse embryos are shown in Table 2. Measurements were made on

TABLE 1

EFFECT OF STORING THE OVARY ON THE LAGTATE DEFYDROGENASE AGTIVITY OF THE OOGYTE

\begin{tabular}{c|c|c}
\hline \multirow{4}{*}{ Experiment } & \multicolumn{2}{|c}{$\begin{array}{c}\text { NADH oxidized/oocyte/hr } \\
\left.\text { (moles } \times 10^{8} \pm S . \text { E. of the mean }\right)\end{array}$} \\
\cline { 2 - 3 } & $\begin{array}{c}\text { Ovary not } \\
\text { stored }\end{array}$ & $\begin{array}{c}\text { Ovary stored } \\
6 \text { hr at } 22^{\circ} C\end{array}$ \\
\hline 1 & $4.90 \pm 0 \cdot 18(14)$ & $4 \cdot 52 \pm 0 \cdot 10(8)$ \\
2 & $4 \cdot 73 \pm 0.18(13)$ & $4 \cdot 71 \pm 0.25(13)$ \\
\hline
\end{tabular}

Figures in parentheses indicate the number of determinations.

oocytes from three different mice and on 2-cell embryos from three different mice. There was no significant difference among the mice contributing the oocytes, or among those contributing the 2-cell embryos. The oocyte data were pooled, and the 2-cell data were pooled, and a comparison indicated that there was no significant difference in the LDH activity of the mouse oocyte and 2-cell embryo.

TABLE 2

COMPARISON OF LDH ACTIVITY IN THE MOUSE OOCYTE AND 2-GELL EMBRYO

\begin{tabular}{|c|c|c|}
\hline \multirow[t]{2}{*}{ Experiment } & \multicolumn{2}{|c|}{$\begin{array}{l}\text { NADH oxidizedloocyte or embryo/hr } \\
\left(\text { moles } \times 10^{8} \pm S . E \text {. of the mean }\right)\end{array}$} \\
\hline & Oocyte & 2-cell \\
\hline $\begin{array}{l}1 \\
1 \\
3\end{array}$ & $\begin{array}{l}5.67 \pm 0.53 \\
4.36 \pm 0.17 \\
4.71 \pm 0.19\end{array}$ & $\begin{array}{l}4.62 \pm 0.22 \\
5.01 \pm 0.34 \\
4.57 \pm 0.13\end{array}$ \\
\hline Total & $4.91 \pm 0.20(24)$ & $4 \cdot 73 \pm 0 \cdot 14(24)$ \\
\hline
\end{tabular}

Figures in parentheses indicate the number of determinations.

A comparison was made between the LDH activity of oocytes and unfertilized ova from New Zealand white rabbits, and the results are shown in Table 3. The experimental design was similar to that used for the mice. There was no significant difference in the activity of the 1-cell ovum taken from three different rabbits, but there was a significant $(0.05>P>0.01)$ difference in the activity of the oocytes from three different rabbits. The data from the oocyte analyses were pooled, and the data from the 1-cell analyses were pooled. A comparison of these two means showed that the unfertilized 1-cell rabbit ovum had a significantly higher $(0.01>P>0.001) \mathrm{LDH}$ activity than the oocyte. 
The LDH activity of the rat oocyte was compared to that of the unfertilized rat ovum, and the activity of the hamster oocyte was compared to that of the unfertilized hamster ovum. These data are shown in Table 4. There was no significant difference between activity in the oocyte and unfertilized ovum in either case.

TABLE 3

COMPARISON OF LDH ACTIVITY IN THE RABBIT OOCYTE AND UNFERTILIZED OVUM

\begin{tabular}{|c|c|c|}
\hline \multirow{2}{*}{ Experiment } & \multicolumn{2}{|c|}{$\begin{array}{l}\text { NADH oxidized/oocyte or ovum } / h r \\
\left(\text { moles } \times 10^{9} \pm S . E \text {. of the mean }\right)\end{array}$} \\
\hline & Oocyte & $\begin{array}{l}\text { Unfertilized } \\
\text { ovum }\end{array}$ \\
\hline $\begin{array}{l}1 \\
2 \\
3\end{array}$ & $\begin{array}{ll}1.27 \pm 0.17 & (8) \\
2.22 \pm 0.33 & (8) \\
1.40 \pm 0.07 & (8)\end{array}$ & $\begin{array}{ll}2.47 \pm 0.24 & (8) \\
2 \cdot 41 \pm 0.25 & (8) \\
1.84 & \pm 0.19\end{array}$ \\
\hline Total & $1.63 \pm 0.12(24)$ & $2 \cdot 24 \pm 0 \cdot 13(24)$ \\
\hline
\end{tabular}

Figures in parentheses indicate the number of determinations.

Activity in oocytes of different strains of mice and breeds of rabbits

The LDH activity of oocytes from six strains of mice was measured to determine the amount of variation in activity within the species. The data are shown in Table 5. The differences between the mice within each strain were not significant. The data for each strain were pooled, and the means for these pooled

TABLE 4

COMPARISON OF LDH ACTIVITY IN THE OOCYTE AND UNFERTILIZED OVUM OF THE RAT AND HAMSTER

\begin{tabular}{|c|c|c|}
\hline \multirow{2}{*}{ Species } & \multicolumn{2}{|c|}{$\begin{array}{l}\text { NADH oxidized/oocyte or ovum/hr } \\
\left(\text { moles } \times 10^{9} \pm S . E . \text { of the mean }\right)\end{array}$} \\
\hline & Oocyte & $\begin{array}{l}\text { Unfertilized } \\
\text { ovum }\end{array}$ \\
\hline $\begin{array}{l}\text { Rat } \\
\text { Hamster }\end{array}$ & $\begin{array}{r}17 \cdot 66 \pm 0.31 \quad(9) \\
5 \cdot 80 \pm 0 \cdot 43(10)\end{array}$ & $\begin{array}{r}16.05 \pm 0.78 \quad(7) \\
5 \cdot 75 \pm 0.54(10)\end{array}$ \\
\hline
\end{tabular}

Figures in parentheses indicate the number of determinations.

data are shown in the last column of the table. The overall mean activity for the 125 oocytes was $5.38 \times 10^{-8}$ moles of NADH oxidized/oocyte/hr. There are a number of cases where the difference in activity between the strains was significant. However, it should be emphasized that, although these are significant differences, the outstanding feature of the data is its close grouping.

Oocytes from four breeds of rabbits were examined for their LDH activity. 
TABLE 5

COMPARISON OF THE LDH ACTIVITY IN THE OOCYTES OF DIFFERENT STRAINS OF MICE

\begin{tabular}{|c|c|c|c|c|}
\hline \multirow[t]{2}{*}{ Strain } & \multicolumn{4}{|c|}{$\begin{array}{c}\text { NADH oxidizedloocyte/hr } \\
\text { (moles } \times 10^{8} \pm S . E \text {. of the mean) }\end{array}$} \\
\hline & Mouse no. 1 & Mouse no. 2 & Mouse no. 3 & Mean \\
\hline Swiss/ICR & $5 \cdot 67 \pm 0.53$ & $\frac{4 \cdot 71 \pm 0 \cdot 19}{(8)}$ & $\begin{array}{c}4 \cdot 36 \pm 0 \cdot 17 \\
(8)\end{array}$ & $\begin{array}{c}4.91 \pm 0.20 \\
(24)\end{array}$ \\
\hline A/JAX & $5 \cdot 27+0 \cdot 26$ & $\frac{5 \cdot 14 \pm 0 \cdot 22}{(8)}$ & $5 \cdot 05 \pm 0.50$ & $\begin{array}{c}5 \cdot 15 \pm 0 \cdot 19 \\
(24)\end{array}$ \\
\hline BALB/C & $5 \cdot 39 \pm 0.23$ & $\frac{6 \cdot 07 \pm 0.31}{(8)}$ & $5 \cdot 39 \pm 0.42$ & $\begin{array}{c}5 \cdot 62 \pm 0 \cdot 19 \\
(24)\end{array}$ \\
\hline C3H/ST & $\underset{(8)}{5 \cdot 72 \pm 0.51}$ & $\underset{(8)}{5 \cdot 48 \pm 0 \cdot 42}$ & $\frac{6 \cdot 56 \pm 0}{(6)}$ & $\begin{array}{c}5 \cdot 92 \pm 0.26 \\
(22)\end{array}$ \\
\hline C57/BL & $\frac{5 \cdot 59}{(8)}+0 \cdot 17$ & $\underset{(8)}{5 \cdot 02 \pm 0 \cdot 25}$ & - & $\begin{array}{c}5 \cdot 31 \pm 0 \cdot 16 \\
(16)\end{array}$ \\
\hline DBA & $4 \cdot 87+0 \cdot 14$ & $5 \cdot 84+0 \cdot 38$ & - & $\begin{array}{c}5 \cdot 36 \pm 0.22 \\
(15)\end{array}$ \\
\hline
\end{tabular}

Figures in parentheses indicate the number of determinations.

These data are shown in Table 6. The difference between animals was not significant for the New Zealand White and Dutch Belted breeds, but was significant for the Chinchilla and Checker breeds. However, when the data for each breed were pooled, the means for the different breeds were similar. Although the values for individual animals are close, the variation is greater than in the mouse.

TABLE 6

COMPARISON OF THE LDH ACTIVITY IN THE OOCYTES OF DIFFERENT BREEDS OF RABBITS

\begin{tabular}{|c|c|c|c|c|}
\hline \multirow[t]{2}{*}{ Breeds } & \multicolumn{4}{|c|}{$\begin{array}{c}\text { NADH oxidizedloocyte/hr } \\
\left(\text { moles } \times 10^{9} \pm S . E \text {. of the mean }\right)\end{array}$} \\
\hline & Rabbit no. 1 & Rabbit no. 2 & Rabbit no. 3 & Mean \\
\hline $\begin{array}{l}\text { New Zealand } \\
\text { White }\end{array}$ & $\frac{1 \cdot 26 \div 0}{(\overline{8})}$ & $2 \cdot 12 \pm 0.37$ & $\frac{1.49}{(8)} \pm 0.24$ & $\begin{array}{c}1.62 \pm 0.17 \\
(24)\end{array}$ \\
\hline Dutch Belted & $\begin{array}{c}1 \cdot 47 \pm 0 \cdot 15 \\
(9)\end{array}$ & $1 \cdot 36 \pm \frac{(8)}{0.14}$ & $1 \cdot 87 \pm \frac{ \pm}{(5)} 0.07$ & $\begin{array}{c}1 \cdot 57 \pm 0 \cdot 10 \\
(22)\end{array}$ \\
\hline Chinchilla & $\begin{array}{c}1 \cdot 32 \pm 0.09 \\
(9)\end{array}$ & $2 \cdot 60 \pm \frac{ \pm}{(7)} 0 \cdot 31$ & $0.90 \pm \frac{ \pm}{(5)} 0.09$ & $\begin{array}{c}1 \cdot 60 \pm 0 \cdot 19 \\
(21)\end{array}$ \\
\hline Checker & $1 \cdot 10 \pm 0.09$ & $2 \cdot 34 \pm 0.21$ & $0.88+0.09$ & $\begin{array}{c}1 \cdot 44 \pm 0 \cdot 16 \\
(24)\end{array}$ \\
\hline
\end{tabular}

Figures in parentheses indicate the number of determinations.

Activity in the oocytes of different species

Oocytes of eight different mammalian species were examined for their LDH activity, and the results are shown in Table 7 . There was a wide range of activities among the species examined. The mouse has by far the highest activity, and the human has the lowest activity per oocyte. Specific activities 
cannot be determined since the amount of protein in the oocyte is not known. However, the diameter of the vitellus of five to ten oocytes was measured for each species before the activity was determined, and this information was used

TABLE 7

COMPARISON OF THE LDH ACTIVITY IN THE OOCYTES OF DIFFERENT

MAMMALIAN SPECIES

\begin{tabular}{|c|c|c|c|c|}
\hline Species & $\begin{array}{c}\text { NADH oxidized }] \\
\text { oocytelhr } \\
\left(\text { moles } \times 10^{9}\right)\end{array}$ & $\begin{array}{c}\text { Diameter of } \\
\text { vitellus } \\
(\mu)\end{array}$ & $\begin{array}{c}\text { Volume of } \\
\text { vitellus } \\
\left(\mu^{3} \times 10^{-5}\right)\end{array}$ & $\begin{array}{c}\text { NADH } \\
\text { oxidized/ } \mu^{3} / h r \\
\left(\text { moles } \times 10^{15}\right)\end{array}$ \\
\hline Mouse & $\begin{array}{l}49 \cdot 10 \pm 2 \cdot 00 \\
\quad(3,24)\end{array}$ & $81 \cdot 5$ & $2 \cdot 83$ & $173 \cdot 50$ \\
\hline Rabbit & $\begin{array}{c}1 \cdot 63 \pm 0 \cdot 12 \\
(3,24)\end{array}$ & $125 \cdot 8$ & $10 \cdot 41$ & 1.57 \\
\hline Rat & $\begin{array}{c}17 \cdot 66 \pm 0 \cdot 31 \\
(1,9)\end{array}$ & $88 \cdot 5$ & $3 \cdot 63$ & $48 \cdot 65$ \\
\hline Hamster & $\begin{array}{c}5 \cdot 80 \pm 0 \cdot 43 \\
(1,10)\end{array}$ & $81 \cdot 3$ & $2 \cdot 81$ & $20 \cdot 64$ \\
\hline Guinea Pig & $\begin{array}{c}3 \cdot 97 \pm 0 \cdot 16 \\
(1,16)\end{array}$ & $80 \cdot 7$ & $2 \cdot 75$ & $14 \cdot 44$ \\
\hline Rhesus Monkey & $\begin{array}{c}6 \cdot 32 \pm 0 \cdot 34 \\
(2,10)\end{array}$ & 115.5 & $8 \cdot 07$ & $7 \cdot 83$ \\
\hline Squirrel Monkey & $\begin{array}{c}1 \cdot 58 \pm 0 \cdot 16 \\
(2,10)\end{array}$ & $92 \cdot 8$ & $4 \cdot 19$ & $3 \cdot 77$ \\
\hline Human & $\begin{array}{c}1 \cdot 30 \pm 0 \cdot 11 \\
(2,8)\end{array}$ & $107 \cdot 7$ & $6 \cdot 54$ & 1.99 \\
\hline Cow & $\begin{array}{c}12 \cdot 35 \pm 0 \cdot 48 \\
(2,13)\end{array}$ & $120 \cdot 0$ & $9 \cdot 05$ & $13 \cdot 65$ \\
\hline Ferret & $\begin{array}{c}6 \cdot 65 \pm 0.81 \\
(1,6)\end{array}$ & $127 \cdot 1$ & $10 \cdot 72$ & $6 \cdot 20$ \\
\hline
\end{tabular}

Figures in parentheses indicate the number of animals and determinations.

to calculate the volume of the vitellus. In the last column of Table 7 is shown the LDH activity per cubic micron of vitellus. The mouse still has the highest activity but, on the basis of volume, the rabbit has the lowest activity.

\section{DISCUSSION}

The first experiments demonstrated that short-term storage of the ovary does not change the LDH enzyme level in the mature oocytes. This is an essential prerequisite to the use of oocytes for studies of LDH activity in a variety of species. It seems probable that the same short storage time would have little effect on many of the other enzymes in the oocytes which might be examined. However, the stability of each enzyme should be examined separately.

In the mouse, rat and hamster there was no significant difference between the LDH activity of the oocytes and the newly ovulated ovum. In the case of the mouse, 2-cell embryos were used rather than unfertilized ova, since the LDH activity of the mouse shows no significant change until the 8-cell stage. However, the LDH activity of the rabbit oocyte was $27 \%$ lower than that in the 
unfertilized newly-ovulated ovum. This seems a small difference in relation to the magnitude of the interspecies difference, and may be due to technical rather than physiological factors. Of all the species, the rabbit corona cells are the most difficult to remove from the oocyte, and they are more difficult to remove from the oocyte than from the ovulated ovum. The mechanical manipulations necessary to remove the corona cells from the oocytes may result in damage to the oocytes and a decrease in the mean activity. On the other hand, the oocytes of the rabbit may have an actual increase in LDH activity with ovulation. In any case, the LDH activity of the oocytes seems to be a good indicator of the activity to be expected in the newly ovulated ovum. In addition, since in the three species where LDH has been examined in all pre-implantation stages (mouse, rat and rabbit), there is little change in total activity during the first 3 days of development, the level of activity in the oocyte appears to be a good indicator of enzyme activity for the early part of the pre-implantation period of embryonic development

Among mice in the same strain there was no significant difference in LDH activity, indicating that one or two animals would serve as a good indication of LDH activity in the strain. Although there were significant differences in the level of activity between strains, the differences were small. The situation is similar within the breeds of rabbits and between the different breeds of rabbits, in that the differences in level of activity are small compared to the mean activity. The variation between rabbits is greater than between mice, which may reflect either greater genetic variation in the rabbit or variation related to the difficult removal of the corona cells from rabbit oocytes. The important outcome of these comparisons is that the intrastrain or intrabreed variation in LDH activity, as well as the variation between strains and breeds in the same species is small, particularly in relation to interspecies differences. Therefore, one or two animals from a species, regardless of the strain or breed, seem to give a fairly reliable indication of the IDH activity in the oocytes of that species. It seems reasonable to expect a similar picture with other enzymes.

The LDH activity of the oocyte in various species is markedly different. In the case of the mouse and rabbit this difference seems to be associated with different nutritional requirements of the pre-implantation embryo. These two species represent the extremes in LDH activity of all the mammalian species so far examined, and it is tempting to speculate that they also represent extremes in dependence on lactate and pyruvate and perhaps extremes in the type of energy metabolism in pre-implantation mammalian embryos. This possibility needs further investigation, and an examination of enzyme patterns in the embryo and oocyte offers a fruitful approach.

\section{ACKNOWLEDGMENTS}

The author gratefully acknowledges the technical assistance of Mrs Mary Reale. Financial support was obtained from the National Institutes of Health (HD-03071), the National Science Foundation (GB-4465) and the Pennsylvania Department of Agriculture (ME-8). 


\section{REFERENCES}

Brinster, R. L. (1965a) Lactic dehydrogenase activity in the preimplanted mouse embryo. Biochim. biophys. Acta, 10, 439.

BRINSTER, R. L. (1965b) Studies on the development of mouse embryos in vitro. II. The effect of energy source. F. exp. Zool. 158, 59.

Brinster, R. L. (1965c) Studies on the development of mouse embryos in vitro. IV. Interaction of energy sources. F. Reprod. Fert. 10, 227.

BRINSTER, R. L. (1968) Lactate dehydrogenase activity in the preimplantation rabbit embryo. Biochin. biophys. Acta, 148, 298.

Fisher, R. A. \& YATEs, F. (1963) Statistical tables for biological, agricultural and medical research, 6th edn. Hafner, New York.

GreenberG, L. J. \& RodDer, J. A. (1964) New precision microcell positioner and cell holder for the Beckman model DU spectrophotometer. Analyt. Biochem. 8, 137. 